\title{
INCIDENCIA DA USUCAPIÃO NOS BENS FORMALMENTE PÚBLICOS: INSTRUMENTO DE EFETIVAÇÃO AO PRINCÍPIO CONSTITUCIONAL DA FUNÇÃO SOCIAL DA PROPRIEDADE E AOS DIREITOS FUNDAMENTAIS COLETIVOS
}

\author{
Givanildo Nogueira Constantino ${ }^{1}$
}

\begin{abstract}
Resumo
A possibilidade de incidência da Usucapião sobre Bens Públicos, no Estado Democrático de Direito Brasileiro, em razão da correta destinação do Bem Público de acordo com as necessidades e interesses populacionais, merece ser objeto de análise, uma vez que, a priori, a inadmissibilidade absoluta decorrente da interpretação dos artigos 183 , \$ $3^{0}$ e 191, parágrafo único, ambos da Constituição Federal de 1988, acompanhada pelo posicionamento da doutrina e da jurisprudência majoritárias - reforçado pelo teor do enunciado da Súmula 340 do Supremo Tribunal Federal - é confrontada por valores e princípios normativos constitucionais, especialmente pelo principio da Função Social da Propriedade, que gera reflexos nas questões atinentes à propriedade. Nesse contexto, verifica-se o posicionamento de expoentes doutrinadores - com respaldo na jurisprudência recente - de que nem todo bem público estaria abarcado pela vedação constitucional à Usucapião, mas, apenas, os Bens Materialmente Públicos. Deste modo, busca-se demonstrar a imprescindibilidade do cumprimento da função social da propriedade e da efetivação dos direitos fundamentais, como o direito à moradia, quando da tutela dos Bens Formalmente Públicos (notadamente os Bens Públicos Dominicais).
\end{abstract}

Palavras-Chave: Bens Formalmente Públicos; Função Social da Propriedade; Aquisição por Usucapião. Prescritibilidade.

\section{INTRODUÇÃO}

A Constituição Federal de 1988 veda, expressamente, nos artigos 183, \3º e 191, parágrafo único, a possibilidade de aquisição da propriedade de bens públicos por meio da usucapião. Observa-se que o cerne dessa proibição reside na tutela dos interesses perseguidos pela Administração Pública, protegendo-se seus bens para que os objetivos almejados possam ser alcançados - e que pertencem, em última análise, ao próprio corpo social. O posicionamento majoritário tanto da doutrina como da jurisprudência acompanha a vedação constitucional, e firma que ela é absoluta, não comportando, por esse motivo, exceção alguma. Tal compreensão é corroborada pelo teor do enunciado da Súmula 340 do Supremo Tribunal Federal. ${ }^{2}$

\footnotetext{
${ }^{1}$ Doutorando em Direito pela FADISP - Faculdade Autônoma de Direito de São Paulo. Professor da Escola da Magistratura do Paraná. E-mail: givanildoconstantinov@hotmail.com

2 Súmula n. 340, STF: "Desde a vigência do Código Civil, os bens dominicais, como os demais bens públicos, não podem ser adquiridos por usucapião”.
} 
Sob o prisma hermenêutico, contudo, a interpretação no que tange à referida proibição, pelo viés do Princípio da Função Social da Propriedade, contido nos artigos 50, inciso XXIII e 170, inciso III, ambos da Carta Magna, deve ser no sentido de se combater esse status absoluto indevidamente atribuído às normas que implicam na vedação da possibilidade de aquisição por usucapião de bens públicos. Isto porque, se infere a existência de determinados "Bens Públicos" que se encontram à deriva, sem qualquer utilidade ou função social, e, por isso, esvaziados no que diz respeito aos objetivos que a própria Constituição lhes impõe.

No plano fático, verifica-se, destarte, que nem todos os bens públicos estão efetivamente destinados ao exercício de atividades que tenham por finalidade o alcance do interesse público. Tratam-se, conforme será visto, daqueles classificados como "Bens Públicos Dominicais"; tais informações demonstram que determinados bens públicos não cumprem sua função, notadamente no que diz respeito a atingir o fim que deles se esperam, quais sejam, o de satisfazer os interesses públicos e necessidades da população, sendo curial, desta maneira, a discussão no que diz respeito a revisão da legitimidade da propriedade dos "Bens Públicos Dominicais".

Por isso, a ilação a que se chega segue no sentido de se admitir a incidência, em determinadas situações, da usucapião sobre Bens Formalmente Públicos e da consequente possibilidade de aquisição por particulares, quando estes proporcionam substrato concreto ao Princípio da Função Social da Propriedade e preenchem os pressupostos legais respectivos, diante da ausência efetiva de destinação pública dos referidos bens pelo Estado.

Desse modo, será analisado o Princípio da Função Social da Propriedade à luz dos dispositivos e princípios constitucionais, para se verificar se a proibição constitucional de se usucapir bens públicos, deve ser tida como vedação iuris tantum, admitindo-se a possibilidade de incidência da usucapião em situações excepcionais com escopo à garantia do interesse público e, consequentemente, à concretização dos direitos fundamentais coletivos, notadamente do direito à moradia.

\section{INSERÇÃO DA EXPRESSÃO "FUNÇÃO SOCIAL DA PROPRIEDADE" NA CONSTITUIÇÃO FEDERAL: REFLEXOS JURÍDICOS NO CONCEITO DE PROPRIEDADE}

De início, cumpre salientar que o termo função social da propriedade parece dispor de certa indeterminação conceitual e semântica. Nesse sentido, Eduardo Espínola busca delimitar o conteúdo da referida expressão, a entendendo, a partir de sua conceituação, como responsável por disciplinar a atividade do proprietário, bem como seus direitos e deveres. ${ }^{3}$

\footnotetext{
${ }^{3}$ Cumpre consignar que o aludido autor aduz que: "não é supérfluo insistir, observa com razão Barassi, que a fórmula, função social, ainda que misteriosa por sua indeterminação, sempre sintetizou as finalidades superiores ao interesse pessoal do proprietário, como meta ulterior para onde deve convergir a gestão do proprietário com as quais deve ser coordenado o seu interesse. A função social se deve entender como expressão destinada a disciplinar a atividade, os direitos e deveres do proprietário" (Cf. ESPÍNOLA, vol.09, no. 04, Rio de Janeiro, 2016. pp. 2507-2525 2508
} 
Neste contexto, também vale trazer a lume o magistério de Fabio Konder Comparato que, na tentativa de apresentar um substrato material à referida expressão, ensina que:

Função, em direito, é um poder de agir sobre a esfera jurídica alheia, no interesse de outrem, jamais em proveito do próprio titular. A consideração dos objetivos legais é, portanto, decisiva nessa matéria, como legitimação do poder. A ilicitude, aí, não advém apenas das irregularidades formais, mas também do desvio de finalidade, caracterizando autêntica disfunção. ${ }^{4}$

Quando se fala em função social da propriedade não se indicam as restrições ao uso e gozo dos bens próprios. Estas últimas são limites negativos aos direitos do proprietário. Mas a noção de função, no sentido em que é empregado o termo nesta matéria, significa um poder, mais especificamente, o poder de dar ao objeto da propriedade destino determinado, de vinculá-lo a certo objetivo. O adjetivo social mostra que esse objetivo corresponde ao interesse coletivo e não ao interesse próprio do dominus, o que não significa que não possa haver harmonização entre um e outro. Mas, de qualquer modo, se se está diante de um interesse coletivo, essa função social da propriedade corresponde a um poder-dever do proprietário, sancionável pela ordem jurídica. ${ }^{5}$

Além disso, mister destacar o entendimento de Léon Duguit, responsável pela modificação definitiva da compreensão do conceito de propriedade, ao considerá-la não como direito individual subjetivo, mas como bem a que se deve atribuir função social - já que ela se apresenta como pressuposto para o êxito do desenvolvimento social e por isso não se pode conferir ao seu detentor direito absoluto, como anteriormente concebido. ${ }^{6}$

No Brasil, a expressão função social da propriedade foi inicialmente empregada na Constituição de 1967, especificamente com a EC/69, na parte relativa à Ordem Econômica, embora o texto constitucional de 1946, já tivesse introduzido a noção de função social, ao condicionar o Direito de Propriedade ao bem estar social. ${ }^{7}$

Contudo, o legislador constituinte originário inovou, ao inserir na atual Constituição Federal, o Princípio da Função Social da Propriedade, no rol dos Direitos e Garantias Fundamentais (art. 5º, XXIII, CF ${ }^{8}$ ), mantendoo, outrossim, entre as bases imprescindíveis da Ordem Econômica (art. 170, II e III, CF9).

Eduardo. Posse, propriedade, compropriedade ou condomínio, direitos autorais. Campinas: Bookseller, 2002. p. 194). Essa ideia do caráter de imprecisão e generalidade conceitual da referida expressão, também é apresentada por Vera Helena de Mello Franco (Cf. FRANCO, Vera Helena de Mello. A função social da empresa. Revista do Advogado, São Paulo, ano 28, v. 96, mar. 2008, p. 131).

${ }^{4}$ COMPARATO, Fabio Konder. A reforma da empresa. São Paulo: Saraiva, 1995. p. 9.

${ }^{5}$ Idem, Ibidem, p. 32. Quanto à semântica referente ao princípio da função social da propriedade, vide também SILVA, José Afonso da. Curso de direito constitucional positivo. 24. ed. São Paulo: Malheiros, 2005. p. 275; CORDEIRO, Carlos José. Usucapião constitucional urbano: aspectos de direito material. São Paulo: Max Limonad, 2001. p. 79; ALBUQUERQUE, Ana Rita Vieira. Da função social da posse. Rio de Janeiro: Lumen Juris, 2002. p. 53.

${ }^{6}$ DUGUIT, Leon. Derecho subjetivo y la función social. In: Las transformaciones del derecho (público y privado). Trad. Carlos Posada. Buenos Aires: Heliasta, 1975.p. 178-179.

${ }^{7}$ CASTRO, Mariângela Conceição Vicente Bergamini de. O princípio da função social da propriedade: empresa. (Dissertação) Universidade de Marília, Marília, 2008.p. 61-62.

${ }^{8}$ Art. 5o Todos são iguais perante a lei, sem distinção de qualquer natureza, garantindo-se aos brasileiros e aos estrangeiros residentes no País a inviolabilidade do direito à vida, à liberdade, à igualdade, à segurança e à propriedade, nos termos seguintes: [...] XXIII - a propriedade atenderá a sua função social.

${ }^{9}$ rt. 170. A ordem econômica, fundada na valorização do trabalho humano e na livre iniciativa, tem por fim assegurar a todos existência digna, conforme os ditames da justiça social, observados os seguintes princípios: [...]

II - propriedade privada;

III - função social da propriedade. 
Desde então, verificou-se um fortalecimento e recorrentes discussões acerca da possibilidade de coexistência entre o Direito de Propriedade e os atributos a ela tradicionalmente reconhecidos (especialmente no que tange ao seu caráter absoluto) e à necessidade de observância ao dever de cumprir sua função social.

Assim, a doutrina posicionou-se, à luz do texto constitucional, no sentido de que os indivíduos têm tutela garantida ao Direito de Propriedade, desde que os bens dos quais detém domínio observem sua função social. ${ }^{10}$ Isto porque a função social passou a integrar a estrutura conceitual de propriedade. ${ }^{11}$ Neste sentido, "a função social é a propriedade, e não algo exterior ao Direito de Propriedade. E, uma vez não cumprida a função social, o Direito de Propriedade será esvaziado." 12

Cumpre consignar, assim, que esse novo pensamento, gerou mudança de paradigma acerca do Princípio da Função Social, como requisito de garantia de tutela ao Direito de Propriedade, tanto sob o prisma de Direito Fundamental, quanto como diretriz norteadora da Ordem Econômica, fato que provocou reflexos nas normas infraconstitucionais posteriores, por exemplo, no artigo $1.228, \$ 1^{\circ}$, do Código Civil..$^{13}$

No entanto, não restaram constatados reflexos unicamente no que tange às normas infraconstitucionais, pois a interpretação das próprias normas constitucionais deve estar atrelada ao Princípio da Função Social da Propriedade. Com efeito, os dispositivos constitucionais que vedam a Usucapião Especial pro morare ou pro labore de Bens Públicos (arts. 183, \$ 30 e 191, parágrafo único, CF) também merecem, necessariamente, ser objeto de estudo, considerando-se as implicações normativas provenientes da principiologia constitucional notadamente do Princípio da Função Social da Propriedade, como escopo primeiro à concretização dos Direitos e Garantias Fundamentais constitucionalmente assegurados.

\footnotetext{
${ }^{10}$ Cumpre destacar que José Diniz de Moraes assevera que: "Se hodiernamente o Direito Individual sobre as coisas impõe deveres em proveito da sociedade e dos não-proprietários, em virtude do princípio da função social, e se a propriedade só é garantida na medida em que garante sua função social, já se pode concluir que ela, como princípio-garantia, reflete em dois sentidos diversos: garante ao proprietário a inviolabilidade do seu domínio quando a satisfaz, impedindo que o legislador ou administrador público empreendam disciplina e atividade diversas, sob o mesmo fundamento; e garante aos interessados medidas idôneas a combater atos incompatíveis com o fundamento da atribuição do domínio, ou em razão dele, quando não atendido o princípio da função social da propriedade". (Cf. MORAES, José Diniz de. A função social da propriedade e a Constituição Federal de 1988. São Paulo: Malheiros, 1999.p. 73).

${ }^{11}$ MORAES, José Diniz, op. cit., p. 106-108. Cf. também GONDINHO, André Osorio. Função social da propriedade. In: TEPEDINO, Gustavo. Problemas de direito civil-constitucional. Rio de Janeiro: Renovar, 2000. p. 398 e 419.

${ }^{12}$ GAMA, Guilherme C. Nogueira; OLIVEIRA, Andrea Leite Ribeiro de. Função social da propriedade e da posse. In: GAMA, Guilherme Calmon Nogueira da. (Coord.). Função social no direito civil. São Paulo: Atlas, 2008. p. 51.

${ }^{13}$ Art. 1.228, $\$ 1$, do CC: "O direito de propriedade deve ser exercido em consonância com as suas finalidades econômicas e sociais e de modo que sejam preservados, de conformidade com o estabelecido em lei especial, a flora, a fauna, as belezas naturais, o equilíbrio ecológico e o patrimônio histórico e artístico, bem como evitada a poluição do ar e das águas".
} 


\section{BENS PÚBLICOS: CONCEITUAÇÃO E EXIGÊNCIA CONSTITUCIONAL DE OBSERVÂNCIA AO PRINCÍPIO DA FUNÇÃO SOCIAL DA PROPRIEDADE}

Preliminarmente, infere-se que Bens Públicos consistem no "conjunto de coisas corpóreas e incorpóreas, móveis, imóveis e semoventes de que o Estado se vale para poder atingir as suas finalidades"; ${ }^{14}$ são os bens sujeitos ao regime jurídico público específico. ${ }^{15}$

Para melhor compreensão dessa temática, é imprescindível que se destaque que os bens podem ser classificados quanto à titularidade em particulares e públicos - sendo os particulares, regidos pelas normas de Direito Civil e, os públicos, pelas de Direito Administrativo ${ }^{16}$, embora o Código Civil disponha a respeito da matéria no artigo 98, de onde se extrai que são considerados públicos os bens de domínio nacional de titularidade das pessoas jurídicas de direito público interno e, particulares, os demais. ${ }^{17}$

No entanto, independentemente de quem seja o titular da propriedade, deverá observar obrigatoriamente o Princípio da Função Social (arts. 5o, XXIII e 170, III, CF) ${ }^{18}$, uma vez que se trata de pressuposto indispensável à legitimação constitucional da tutela ao Direito de Propriedade sobre determinado bem.

Nesta perspectiva, torna-se pertinente trazer à luz o conceito da expressão "domínio público", ou, "dominialidade pública”, ou seja, a definição jurídica atribuída ao conjunto de Bens Públicos ${ }^{19}$. Em assim sendo, domínio público se apresenta em poderes de soberania e em direitos de propriedade; a soberania é exercida de acordo com o interesse público, enquanto que os direitos de propriedade atingem apenas os bens pertencentes às entidades públicas, ou seja, aquela se apresenta como domínio eminente, enquanto que esta se apresenta como domínio patrimonial. ${ }^{20}$

Ademais, o domínio patrimonial do Estado, que recai sobre os bens, é Direito de Propriedade. Todavia, referido domínio consiste em Direito de Propriedade Pública - subordinado a um regime jurídico administrativo

\footnotetext{
${ }^{14}$ BASTOS, Celso Ribeiro. Curso de direito administrativo. São Paulo: Celso Bastos, 2002. p. 449.

${ }^{15}$ PESTANA, Marcio. Direito administrativo brasileiro. Rio de Janeiro: Elsevier, 2008. p. 409. Ainda no que tange à definição de bens públicos, vide CRETELLA JÚNIOR, José. Manual de direito administrativo. Rio de Janeiro: Forense, 2005. p. 291.

${ }^{16}$ DOWER, Nelson Godoy Bassil. Curso moderno de direito civil. São Paulo: Nelpa, 2004. p. 242. Cf. também NADER, Paulo. Curso de direito civil: parte geral. Rio de Janeiro: Forense, 2003. p. 353.

${ }^{17}$ Cf. Art. 98 do Código Civil: "São públicos os bens do domínio nacional pertencentes às pessoas jurídicas de direito público interno; todos os outros são particulares, seja qual for a pessoa a que pertencerem”.

${ }^{18}$ NADER, Paulo, op. cit., p. 354.

${ }^{19}$ MELLO, Celso Antônio Bandeira de. Curso de direito administrativo. 27. ed. São Paulo: Malheiros, 2010. p. 913. Este também é o conceito adotado por Odete Medauar. (Cf. MEDAUAR, Odete. Direito administrativo moderno. São Paulo: Revista dos Tribunais, 2010. p. 245).

${ }^{20}$ RIBEIRO, Benedito Silvério. Tratado de usucapião. São Paulo: Saraiva, 2012. v. 1. p. 492. No que tange ao domínio público, vide também BASTOS, Celso Ribeiro, op. cit., p. 447. No entanto, há quem destaque que a expressão domínio público é equívoca, no sentido de que admite vários significados (Cf. DI PIETRO, Maria Sylvia Zanella. Direito administrativo. São Paulo: Atlas, 2012. p. 727-728). Hely Lopes Meirelles também ressalta o caráter equívoco da expressão domínio público. (MEIRELES, Hely Lopes. Direito administrativo brasileiro. São Paulo: Malheiros, 2010. p. 546).
} 
especial, com regras específicas, incidindo na espécie, apenas de modo supletivo, as regras do Direito Civil, no que tange à propriedade privada. ${ }^{21}$

Com relação à natureza jurídica dos Bens Públicos, ou seja, no que pertine à propriedade regida pelo Direito Público, é importante destacar que a propriedade regida pelo domínio público detém semelhanças com a propriedade privada, principalmente no tocante aos direitos e deveres que a Administração exerce sobre o bem, em relação à mesma atividade realizada pelo ente privado; entretanto, há também diferenças, como o fato de a Administração Pública possuir prerrogativas que o particular não tem, sendo o exercício do poder de polícia, um exemplo.

Por essas razões, a teoria da propriedade pública possui características peculiares, que a diferem da propriedade privada, que lhes são conferidas pelo instituto da Afetação ${ }^{22}$, que nada mais é do que a "preposição de um bem a um dado destino categorial de uso comum ou especial" ${ }^{23}$, ou seja, este instituto nada mais é do que a caracterização de um fato administrativo que tem como finalidade atribuir ao bem público destinação especial, de acordo com os interesses direitos ou indiretos do órgão governamental ${ }^{24}$.

Em virtude disso, cumpre ressaltar os traços distintivos conferidos à propriedade pública, pelo instituto da Afetação:

Os bens dessas entidades - corpóreos e incorpóreos, móveis e imóveis, qualquer que seja a sua utilização - estão integralmente sujeitos a regime jurídico próprio, o denominado "regime jurídico dos bens públicos", traduzido nas características de imprescritibilidade, impenhorabilidade, não onerabilidade e na existência de restrições e condicionamentos a sua alienação (inalienabilidade relativa). ${ }^{25}$

Observa-se que é importante, nessa circunstância, a existência de domínio público, isto é, que o Estado seja proprietário de determinados bens, até porque tal condição é imprescindível para que se possa imprimir normal atendimento ao interesse público e ao bem estar social. ${ }^{26}$

Neste ínterim, é pertinente a apresentação de dois conceitos importantes com relação aos Bens Públicos que são os Institutos da Afetação e da Desafetação. A primeira se dá quando se atrela a determinado bem uma destinação de uso comum ou especial. ${ }^{27}$ Deste modo, conforme Paulo Nader, "a espécie dominial não se presta à afetação, pois são bens, por sua natureza, sem função específica". ${ }^{28}$ Vale ressaltar que, segundo Petrônio Braz, a "afetação de um bem ao uso público não se efetiva de maneira permanente, porque só perdurará enquanto o bem

\footnotetext{
${ }^{21}$ RIBEIRO, Benedito Silvério, op. cit., p. 493.

${ }^{22}$ DI PIETRO, Maria Sylvia Zanella, op. cit., p. 729-730.

${ }^{23}$ MELLO, Celso Antônio Bandeira de. Curso de Direito Administrativo. 27. ed. rev. e atual. São Paulo: Malheiros, 2010.

${ }^{24}$ CARVALHO FILHO, José dos Santos. Manual de Direito Administrativo. 24. ed. rev., ampl. e atual. Rio de Janeiro: Lumen Júris, 2011.

${ }^{25}$ ALEXANDRINO, Marcelo; PAULO, Vicente. Direito administrativo descomplicado. São Paulo: Método, 2014. p. 1.000.

${ }^{26}$ BASTOS, Celso Ribeiro, op. cit., p. 445. Sobre bens de uso comum do povo, vide ainda AMARAL, Francisco. Direito civil: introdução. Rio de Janeiro: Renovar, 2002. p. 324.

${ }^{27}$ MELLO, Celso Antônio Bandeira de, op. cit., p. 915.

${ }^{28}$ NADER, Paulo, op. cit., p. 360. Cf. também ALEXANDRINO, Marcelo; PAULO, Vicente, op. cit., p. 1009.
} 
conservar essa qualidade". ${ }^{29}$

Já a desafetação exterioriza a desconstituição de uma afetação, alterando a qualidade do bem que passa ao grupo dos Bens Dominais, ficando, eventualmente, sujeito a alienação aos particulares. ${ }^{30}$ Segue também no mesmo sentido a definição de afetação e desafetação, apresentada por Celso Antônio Bandeira de Mello. ${ }^{31}$

Vislumbra-se, neste cenário, como já ressaltado, que a função social da propriedade deve ser cumprida por seus titulares (sejam eles particulares ou pessoas jurídicas de direito público interno), pois quando do estabelecimento do princípio respectivo na ordem constitucional (art. 5, XXIII e art. 170, III, CF), o legislador constituinte não fez nenhuma ressalva, situação que conduz à conclusão de que, tanto o Estado como o particular, estão adstritos a essa mesma diretiva normativa, pois seria incongruente aceitar que o Estado fosse posto em situação diferente, ou seja, que a ele não se impusesse o ônus de portador do dever de atribuição de função social aos seus bens.

Desta forma, depreende-se que o uso dos Bens Públicos deve estar sempre atrelado ao Interesse Público. Este também é o entendimento de Cristiana Fortini, que se manifesta a respeito da seguinte forma:

A Constituição da República não isenta os bens públicos do dever de cumprir função social. Portanto, qualquer interpretação que se distancie do propósito da norma constitucional não encontra guarida. Não bastasse a clareza do texto constitucional, seria insustentável conceber que apenas os bens privados devam se dedicar ao interesse social, desonerando-se os bens públicos de tal mister. Aos bens públicos, com maior razão de ser, impõe-se o dever inexorável de atender à função social..$^{32}$

A necessidade de atendimento ao Princípio da Função Social pelos detentores da propriedade dos bens - inclusive os públicos, com efeito, é basilar para que tais proprietários possam ser dignos de receber a tutela ao seu Direito de Propriedade, assegurada pela Constituição Federal (arts. 50, XXIII e 170, III, CF).

\section{BENS FORMALMENTE PÚBLICOS: ADMISSIBILIDADE DE AQUISIÇÃO POR USUCAPIÃO - PRESCRITIBILIDADE}

A partir do momento em que a observância ao Princípio da Função Social pelos detentores de bens, passou a integrar o próprio conceito de propriedade, inclusive dos meios de produção, restaram constatadas implicações quanto à necessidade de alteração de paradigmas em diversos institutos jurídicos, até mesmo no que tange à possibilidade de aquisição de Bens Públicos por Usucapião. Tais desdobramentos de ordem constitucional e infraconstitucional também foram objeto de preocupação do legislador constituinte. Neste sentido, é importante ressaltar que o legislador constituinte reconheceu a função social da propriedade, sobretudo

\footnotetext{
${ }^{29}$ BRAZ, Petrônio. Manual de direito administrativo. Leme: Editora de Direito, 2001. p. 566.

${ }^{30}$ NADER, Paulo, op. cit. p. 361. Com relação aos institutos da afetação e desafetação, vide também BASTOS, Celso Ribeiro, op. cit., p. 452; ALEXANDRINO, Marcelo; PAULO, Vicente, op. cit., p. 1.010.

${ }^{31}$ MELLO, Celso Antônio Bandeira de, op. cit., p. 915.

${ }^{32}$ FORTINI, Cristiana. A função social dos bens públicos e o mito da imprescritibilidade. Revista Brasileira de Direito Municipal, vol.09, nº. 04, Rio de Janeiro, 2016. pp. 2507-2525 2513
} 
no que diz respeito aos artigos 183 e 191, ambos da Carta Magna, valendo ser ressaltado, ademais, que, com a criação daquele dispositivo, o legislador buscou criar uma nova espécie de usucapião, a constitucional urbana ou pro morare. Por outro lado, as disposições do artigo 191 tem o escopo de modificar a usucapião especial rural ou pro labore; essa mudança foi efetivada, principalmente, em razão das mazelas enfrentadas nas grandes cidades, que abarcam imóveis abandonados ou irregularmente utilizados. ${ }^{33}$

Desta forma, vale esclarecer que a usucapião tem origem no latim usucapio, de usucapere (usucapir) e expressa a maneira de se adquirir um bem em virtude do uso ou da prescrição. Assim, a usucapião é forma originária de aquisição de propriedade e ocorre diante do exercício da posse mansa e pacífica sobre um bem específico, por prazo definido na lei, sem prejuízo de preenchimento de outros pressupostos legalmente exigidos. 34

Em se tratando de Bens Públicos, há vedação constitucional expressa quanto ao reconhecimento e caracterização da usucapião, seja na modalidade pro morare (art. 183, \ 3º, CF) ou na pro labore (art. 191, parágrafo único, CF). Ademais, dita vedação também é expressa no âmbito infraconstitucional, consoante o teor do artigo 102, do Código Civil.

A vedação a aquisição prescritiva, por usucapião, de bens públicos, tem o escopo de proteger o patrimônio estadual e os interesses inerentes ao órgão governamental, valendo asseverar que os dispositivos legais não fazem qualquer distinção entre as categorias de bens públicos, entretanto, tais disposições entram em conflito com o Princípio da Função Social da Propriedade, mormente quando o bem de propriedade do Estado não cumpre qualquer função.

Neste ponto, vale asseverar que embora sejam imprescritíveis os Bens Públicos de uso comum do povo e os de uso especial, há entendimento doutrinário no sentido de ser possível a hipótese da usucapião no que tange aos Bens Dominicais; para isso, é necessário perfazer prelúdio histórico legal, para melhor compreensão do tema.

Em um primeiro momento, podiam-se usucapir Bens Públicos patrimoniais ou Dominicais, desde que preenchidos requisitos legais, consistentes, dentre eles, na posse pelo prazo de 40 (quarenta) anos. Esse entendimento é fundamentado pela antiga doutrina Portuguesa que, por sua vez, tomavam como base o Direito Romano; porém, juristas pátrios clássicos, após pesquisa, modificaram esse paradigma, afirmando, para tanto, a imprescritibilidade dos Bens Públicos patrimoniais, tendo o tema passado, desde então, por inúmeras debates e discussões, chegando ao seu ápice com a promulgação da Constituição Federal de 1988, momento em que se

\footnotetext{
Belo Horizonte, ano 5, n. 12, abril/junho, 2004. p. 117.

${ }^{33}$ CORDEIRO, Carlos José, p. 84.

${ }^{34}$ ZACARIAS, André Eduardo de Carvalho. Anotaçôes sobre a usucapião: de acordo com a Lei n. 10.406/2002. Leme: Edijur, 2006. p. 16. Com relação à origem da palavra usucapião, vide ainda RIBEIRO, Benedito Silvério, op. cit., p. 63. Quanto ao conceito de usucapião, vide OLIVEIRA, Arlindo Uilton de. Usucapião urbano e rural. Presidente Prudente: Data juris, 1994. p. 15.
} 
positivou, no artigo 191, parágrafo único, que "os imóveis públicos não serão adquiridos por usucapião". 35

As menções expressas inseridas na Constituição Federal de 1988 quanto à imprescritibilidade do Bem Público, conduziram a maioria da doutrina a adotar interpretação literal dos dispositivos em questão e, consequentemente, a defender a tese de que tais proibições seriam absolutas. Isto significaria dizer que o Bem Público não é passível de aquisição por usucapião, sendo irrelevante o contexto em que ele se encontra ou a sua destinação (Bem Público de uso comum, de uso especial e dominicais/dominiais) ${ }^{36}$

No entanto, quando se trata da questão que envolve a eventual viabilidade da aquisição por usucapião de Bens Públicos, emerge a importância de se apontar a classificação doutrinária, que os divide entre Bens Formalmente Públicos e Bens Materialmente Públicos. Tal classificação é explicada com propriedade por Cristiano Chaves de Farias e Nelson Rosenvald que afirmam o seguinte:

Os bens públicos poderiam ser divididos em materialmente e formalmente públicos. Estes seriam aqueles registrados em nome da pessoa jurídica de Direito Público, porém excluídos de qualquer forma de ocupação, seja para moradia ou exercício de atividade produtiva. Já os bens materialmente públicos seriam aqueles aptos a preencher critérios de legitimidade e merecimento, postos dotados de alguma função social..$^{37}$

Desse modo, quanto à possibilidade de aquisição do bem público por usucapião, "no perfil atual da propriedade, a titularidade, isoladamente considerada, é insuficiente; prepondera a sua legitimidade e a destinação". ${ }^{38}$ Neste sentido, conclui-se que não é porque a pessoa jurídica de direito público interno seja titular de determinado bem que estará necessariamente protegida sob o manto da vedação constitucional à usucapião, mas para que isso ocorra, terá ela que atribuir ao bem uma função social que se encontre expressa na vinculação ao interesse público.

Assim, somente com o preenchimento do substrato público ao bem de titularidade pública, é que incidiriam os dispositivos constitucionais de proibição à usucapião, pois aqui, sim, se estaria diante de um autêntico Bem Público, ou seja, daquele que a doutrina denomina como Bem Materialmente Público e digno, portanto, de blindagem constitucional à incidência da usucapião.

Já no que tange aos Bens Formalmente Públicos, o entendimento que gira em torno da existência de vedação absoluta à incidência da usucapião é questionável quando o particular que os possui, diante da negligência estatal à destinação social ou à atribuição de finalidade pública, lhes propicia função social. Este é, também, o posicionamento de Cristiana Fortini:

\footnotetext{
${ }^{35}$ RÁO, Vicente. O Direito e a vida dos direitos. São Paulo: Revista dos Tribunais, 2013. p. 779.

${ }^{36}$ LÔBO, Paulo. Direito civil: parte geral. São Paulo: Saraiva, 2012. p. 208; NOHARA, Irene Patrícia, op. cit., p. 696-697; CARVALHO FILHO, José dos Santos. Manual de direito administrativo. 27. ed. Rio de Janeiro: Lumen Juris, 2014. p. 1.172; ARAÚJO, Fabio Caldas de. O usucapião no âmbito material e processual. Rio de Janeiro: Forense, 2002. p. 155-156.

${ }^{37}$ FARIAS, Cristiano Chaves de; ROSENVALD, Nelson. Direitos reais. Rio de Janeiro: Lumen Juris, 2006. p. 267.

${ }^{38}$ Idem, Ibidem, p. 209.
} vol.09, nº. 04, Rio de Janeiro, 2016.pp. 2507-2525 


\begin{abstract}
A Constituição da República, ao afastar a possibilidade de usucapião de bens públicos, pretendeu acautelar os bens materialmente públicos, ou seja, aqueles que, pela função a que se destinam, exijam proteção, sob pena de sacrificar o interesse público. [...] Interpretação diversa se distancia da correta exegese da Constituição da República porque implica a mitigação da exigência constitucional de que a propriedade pública e a privada cumpram função social. ${ }^{39}$
\end{abstract}

Não obstante a resistência oferecida pela doutrina e pela jurisprudência majoritárias em reconhecer a possibilidade de incidência da usucapião sobre os Bens Formalmente Públicos, já se constata a presença nos Tribunais, de posições favoráveis ao entendimento esposado por essa outra corrente doutrinária, ainda que minoritárias, que são motivadas, principalmente, pela observância ao princípio da Função Social da Propriedade, ao compará-lo com o interesse e a atividade exercida pelo ente estadual no respectivo imóvel, ou seja, as decisões são fundamentadas a partir do desempenho do órgão do Estado, somado ao interesse público inerente à esta atividade. ${ }^{40}$

O que se verifica, neste panorama, é que os Bens Públicos de uso comum do povo e os de uso especial, pelo fato de estarem diretamente afetados, ou seja, vinculados a um interesse público específico - resguardadas as peculiaridades já demonstradas - cumprem, consequentemente, uma determinada função social e, portanto, de fato, não são passíveis de aquisição pela usucapião (arts. 183, \$ $3^{\circ}$ e 191, parágrafo único, CF).

No entanto, considerando que os Bens Públicos Dominicais são aqueles que estão desafetados, isto é, carentes de qualquer interesse público a eles vinculados - mas, que, conforme, o teor do artigo 99, inciso III, do Código Civil, "constituem o patrimônio das pessoas jurídicas de direito público, como objeto de direito pessoal, ou real, de cada uma dessas entidades" -, a possibilidade de incidência da usucapião sobre tal espécie de Bem Público é questão que chama a atenção diante da alteração do panorama jurídico, colocando em xeque a visão majoritária que caracteriza a vedação constitucional respectiva como absoluta. Assim, infere-se que existe a necessidade premente de revisão de conceitos para que pontos de vista estagnados venham a ser flexibilizados, pelo menos quanto a aspectos específicos, relativizando-se posicionamentos que há pouco eram adequados, mas que, contemporaneamente, com a evolução social e normativa, acabaram se tornando arcaicos.

Segundo Maria Sylvia Zanella Di Pietro, a afetação de determinado Bem Público ao uso coletivo ou à utilização da Administração é o que efetivamente diferencia os Bens Públicos de uso comum do povo e de uso

\footnotetext{
${ }^{39}$ FORTINI, Cristiana, op. cit., p. 120.

${ }^{40}$ BRASIL. Tribunal de Justiça do Estado de São Paulo. Acórdão no 0038178-14.2006.8.26.0000. Primeira Câmara de Direito Privado. São Paulo 18 set. 2013. Disponível em: < http://tj-sp.jusbrasil.com.br/jurisprudencia/117746795/ apelacao-apl381781420068260000-sp-0038178-1420068260000/inteiro-teor-117746805>. Acesso em: 15 maio 2015;

BRASIL. Tribunal de Justiça do Estado da Bahia. Acórdão no 0000005-47.2007.8.05.0071. Quinta Câmara Cível. Salvador 15 out. 2013. Disponível em: < http://tj-ba.jusbrasil.com.br/jurisprudencia/115799360/apelacao-apl-54720078050071-ba-00000054720078050071/inteiro-teor-115799369>. Acesso em: 15 maio 2015e, e;

BRASIL. Tribunal de Justiça do Estado do Rio Grande do Sul. Acórdão no 70057295933. Vigésima Câmara Cível. Porto Alegre 26 mar. 2014. Disponível em: < http://tj-rs.jusbrasil.com.br/jurisprudencia/115239106/apelacao-civel-ac-70057295933-rs>. Acesso em: 15 maio 2015.
} 
especial dos denominados Bens Públicos Dominicais, ${ }^{41}$ também denominados como Bens Formalmente Públicos.

Considerando, assim, que os Bens Públicos Dominicais são bens desafetados, o que se infere é que o Instituto da Usucapião é plenamente passível de incidência na espécie e se caracteriza, portanto, como instrumento hábil à concretização do Princípio da Função Social da Propriedade. Desta forma, consoante magistério de José Carlos de Moraes Salles:

[...] todo bem, móvel ou imóvel, deve ter uma função social. Vale dizer, deve ser usado pelo proprietário, direta ou indiretamente, de modo a gerar utilidades. Se o dono abandona esse bem; se se descuida no tocante a sua utilização, deixando-o sem uma destinação e se comportando desinteressadamente como se não fosse o proprietário, pode, com tal procedimento, proporcionar a outrem a oportunidade de se apossar da aludida coisa. Essa posse, mansa e pacífica, por determinado tempo previsto em lei, será hábil a gerar a aquisição da propriedade por quem seja seu exercitador, porque interessa à coletividade a transformação e a sedimentação de tal situação de fato em situação de direito. À paz social interessa a solidificação daquela situação de fato na pessoa do possuidor, convertendo-a em situação de direito, evitando-se, assim, que a instabilidade do possuidor possa eternizar-se, gerando discórdias e conflitos que afetem perigosamente a harmonia da coletividade. ${ }^{42}$ (grifo nosso).

Com efeito, ao contrário do que ocorre com os Bens Públicos de uso comum do povo e com os de uso especial, os Bens Públicos Dominicais são passíveis de aquisição por usucapião, pois, em que pese terem status de públicos - uma vez que são de titularidade do Estado, este, ao deles dispor, se comporta como Particular, sujeitando-se, desta forma, ao regime privado; referidos bens não estão, portanto, abarcados pelas disposições contidas nos artigos 183, \$3º e 191, parágrafo único, ambos da Constituição Federal de 1988. ${ }^{43}$

Todavia, vale salientar que não é correta eventual afirmação no sentido de que nenhum Bem Público Dominical cumpre sua função social, porque o Estado pode utilizá-lo, por exemplo, como fonte de renda ${ }^{44}$, atribuindo-lhe, neste caso, função patrimonial e observando, via de consequência, o princípio respectivo, não havendo que se falar, no caso, em qualquer possibilidade de aquisição por usucapião.

No entanto, são os Bens Públicos dessa natureza, que estão mais sujeitos à desvinculação quanto ao atendimento do interesse público, ao passo que simultânea e paradoxalmente poderá ser constatada a inércia estatal, de um lado e, de outro, particulares que se encontram na posse de tais bens, seja a que título for - tudo dependerá da análise do caso concreto - que ajam durante o exercício da posse com observância estrita a tal princípio, atribuindo-lhe função social extrema, conforme os ditames legais, o que ensejaria, de fato e de direito, a possibilidade de reivindicar sua propriedade pela usucapião, desde que os demais pressupostos legais encontrem-

\footnotetext{
${ }^{41}$ DI PIETRO, Maria Sylvia Zanella, op. cit., p. 728-729.

${ }^{42}$ SALLES, José Carlos de Moraes. Usucapião de bens imóveis e móveis. 2. ed. Rio de Janeiro: Revista dos Tribunais, 1992. p. 26.

${ }^{43}$ BASTOS, Celso Ribeiro, op. cit., p. 454.

${ }^{44}$ Quanto à relação entre os bens dominicais e renda, cumpre destacar as ideias de José Cretella Júnior: "Os bens dominicais produzem renda, constituindo propriamente o patrimônio do Estado. As denominadas 'receitas originárias' são oriundas desses vol.09, no. 04, Rio de Janeiro, 2016. pp. 2507-2525 2517
} 
se rigorosamente preenchidos.

Neste contexto, insta registrar que há autores que defendem a necessidade de o Poder Público destinar finalidade pública aos Bens Dominicais, ainda que estes ensejem renda para o Estado, pois os Bens Públicos não poderiam ter apenas substrato meramente patrimonial. ${ }^{45}$

Ademais, autores como Cristiano Chaves de Farias e Nelson Rosenvald, reforçam o entendimento sobre a viabilidade da aquisição por usucapião, de determinados Bens Públicos, quando eles estiverem carentes de vinculação ao interesse público por parte do Estado, em detrimento da função social que está sendo atribuída pelo particular ao referido bem, argumentando que "a absoluta impossibilidade de usucapião sobre Bens Públicos é equivocada, por ofensa ao Princípio Constitucional da Função Social da Posse, em última instância, ao próprio Princípio da Proporcionalidade". ${ }^{46}$

Com relação à Função Social da Posse, mister esclarecer que ela preconiza que o possuidor não deve quedar-se inerte, muito pelo contrário, deve ele utilizar o bem de modo a efetivar os serviços e as qualidades que dele podem ser extraídas; portanto, o comportamento do possuidor é dinâmico em relação à propriedade, para que seja atingida sua função social, que gera, por conseguinte, bem estar na sociedade, razão pela qual, a usucapião, com base nestes fundamentos, é imprescindível ao equilíbrio social. ${ }^{47}$

Com efeito, a "função social da posse importa, ainda, em representar o conteúdo da vontade do possuidor, não podendo mais significar uma vontade vazia, na expressão de Hegel, mas uma vontade dotada de conteúdo próprio, do conteúdo social." ${ }^{48}$

Na verdade, o que se verifica é que o Princípio da Função Social da Propriedade e o Princípio da Função Social da Posse estão intimamente imbricados quando ambos se deparam com o Instituto da Usucapião. Tal perspectiva é bem ressaltada por Guilherme Calmon Nogueira da Gama:

\begin{abstract}
A função social da propriedade e a função social da posse, na verdade, são os dois lados de uma mesma moeda. A posse, como conteúdo do direito, é indispensável à propriedade para que esta cumpra sua função social e recebe proteção do sistema. A posse em si mesma é importante para a sociedade, pois é através dela que o homem pode atender as suas necessidades vitais, como a moradia e o cultivo (trabalho rural). ${ }^{49}$
\end{abstract}

\footnotetext{
bens, objetos com os quais o Estado tem relação de propriedade. Trata-se de bens explorados pelo Estado com intuito de lucro, graças a atividades diretas exercidas sobre elas" (Cf. CRETELLA JÚNIOR, José, op. cit., p. 320-321).

${ }^{45}$ MARÇAL, Thaís Boia; OLIVEIRA, Rafael Carvalho Rezende. A função social e a usucapião de bens públicos: uma releitura a partir da constitucionalização do ordenamento jurídico. Boletim de Direito Administrativo - BDA, São Paulo: NDJ, dez/2013, p. 1261- 1275 .

${ }^{46}$ FARIAS, Cristiano Chaves de; ROSENVALD, Nelson, op. cit., p. 267.

${ }^{47}$ CORDEIRO, Carlos José, op. cit., p. 96-97.

${ }^{48}$ ALBUQUERQUE, Ana Rita Vieira. Da função social da posse. Rio de Janeiro: Lumen Juris, 2002. p. 204-205.

${ }^{49}$ GAMA, Guilherme Calmon Nogueira; OLIVEIRA, Andrea Leite Ribeiro de, op. cit., p. 64.
} vol.09, nº. 04, Rio de Janeiro, 2016.pp. 2507-2525 
Desta forma, o Instituto da Usucapião Imobiliária requer destaque, posto que "sua concretização apresenta-se, no contexto do Direito, como a cristalização da proteção das relações e interesses intersubjetivos" ${ }^{50}$

As terras devolutas, por outro lado, constituem, conforme exposto, exemplo de Bens Públicos Dominicais. ${ }^{51}$ Acerca do tema, Celso Ribeiro Bastos destaca que:

As terras devolutas constituem o maior contingente que compõe o domínio público. Nada obstante serem públicas em razão da qualidade que detém a sua titularidade, não tem essa qualificação quando se leva em conta a destinação a que estão afetas. As terras devolutas não estão vinculadas ao atingimento de um fim público. Permanecem como um estoque de terras ainda não transpassado aos particulares ou, tendo um dia estado em suas mãos, já tornaram à origem em razão do donatário ter caído em comisso. O fato é que estas terras são possuídas pelos Poderes Públicos à moda de um particular. Devem, portanto, estar sujeitas ao usucapião, não colhidas, pois, pela expressão "imóveis públicos" a que se referem os arts. 183 e 191 da Constituição Federal. ${ }^{52}$

Neste mesmo sentido, Hely Lopes Meirelles:

Terras devolutas são todas aquelas que, pertencentes ao domínio público de qualquer das entidades estatais, não se acham utilizadas pelo Poder Público, nem destinadas a fins administrativos específicos São bens públicos patrimoniais ainda não utilizados pelos respectivos proprietários. ${ }^{53}$

Neste cenário, não é possível admitir que o Estado permaneça como proprietário de um conjunto significativo de terras desprovidas de finalidade pública - impedindo a aquisição destas por sujeitos que as tornaram produtivas e nelas consolidaram moradia em observância ao interesse público - porque isso implicaria em ofensa ao Princípio da Função Social da Propriedade - diretriz constitucional (arts. 50 XXIII e 170, III, CF) que deve incidir independentemente de quem seja o titular do bem (particular ou pessoa jurídica de direito público interno). A vedação constitucional à aquisição do bem por usucapião, neste contexto, vale reafirmar, incidiria apenas sobre os incisos I e II do artigo 99 do Código Civil. ${ }^{54}$

Em última instância, ao se admitir a aquisição por usucapião especial pro morare ou pro labore de determinado Bem Formalmente Público pelo particular que a ele propiciou função social, efetiva-se os Direitos Fundamentais, especialmente, o de moradia (art. $\left.6^{\circ}, \mathrm{CF}\right)$. No que diz respeito ao Direito de Moradia, vale salientar que:

Esse é daqueles direitos que têm duas faces: uma negativa e uma positiva. A primeira significa que o cidadão não pode ser privado de uma moradia nem impedido de conseguir uma, no que importa a abstenção do Estado e de terceiros. A segunda, que é a nota principal do direito à moradia, como dos demais direitos sociais, consiste no direito de obter uma

\footnotetext{
${ }^{50}$ CORDEIRO, Carlos José, op. cit. p. 79-80. Ainda assim este autor aponta a relevância da usucapião: "A usucapião, desde as suas remotas origens, permitindo consolidar a propriedade em favor daquele que, possuindo como seu por tempo prolongado, trabalhou o bem e o reintegrou em sua função econômico-social, constitui-se em valioso elemento gerador de riquezas, contribuindo para o incremento do bem-estar coletivo e, consequentemente, para atenuar as tensões sociais."

${ }^{51}$ GASPARINI, Diogenes, op. cit., p. 1.019.

${ }^{52}$ BASTOS, Celso Ribeiro, op. cit., p. 459.

${ }^{53}$ MEIRELLES, Hely Lopes, op. cit., p. 579-580.

${ }^{54}$ DANTAS, Francisco Wildo Lacerda. A reforma agrária e a usucapião pro labore. In: Revista de Informação Legislativa. Brasília: Senado Federal, Subsecretaria de Edições Técnicas, ano 33, n. 131, jul./set., 1996, p. 259.
} 
moradia digna e adequada, revelando-se como um direito positivo de caráter prestacional, porque legitima a pretensão do seu titular à realização do direito por via de ação positiva do Estado. ${ }^{55}$

Com efeito, se o Bem Público Dominical encontra-se integralmente alheio aos respectivos cuidados estatais, no sentido de disposição de destinação específica vinculada ao interesse público, não há empecilho para que ele possa ser adquirido por particular quando este possuir o imóvel como único dono, usufruindo dele para fins de moradia própria e da família e cumprindo os demais requisitos legalmente exigidos.

Neste caso, a conclusão a que se chega é a de que existe plena possibilidade de aquisição do bem pela usucapião especial urbana, não subsistindo, destarte, a vedação constitucional contida no $₫ 3^{\circ}$ do artigo 183 da Constituição Federal, porque a função social atribuída à propriedade propiciou a efetivação ao Direito Fundamental de Moradia, assegurado pelo artigo $6^{\circ}$ da Carta Magna, direito este intimamente ligado ao Princípio da Dignidade da Pessoa Humana. Tal entendimento também se aplica à usucapião especial rural, a que faz menção o artigo 191 da Constituição Federal, valendo observar que nesta modalidade, é necessário também que a terra seja tornada produtiva - sendo insuficiente a mera fixação de moradia.

Ademais, insta ressalvar que a inobservância ao dever social atribuído ao proprietário de determinado bem - particular ou público, como assevera Guilherme Calmon Nogueira da Gama -, implica em "lesão aos direitos fundamentais de acesso à propriedade, ao trabalho e à moradia, reconhecidos pelo sistema constitucional." 56

Torna-se imperioso ressaltar, neste contexto, que embora a doutrinadora Odete Medauar defenda a posição de que a "imprescritibilidade tem por finalidade, sobretudo, a preservação dos bens públicos, protegendoos até contra a negligência da própria Administração", ${ }^{57}$ referida característica - imprescritibilidade - tal como se apresenta nos artigos 183, $\$ 3^{\circ}$ e 191, parágrafo único, ambos da Constituição Federal -, foi conferida aos Bens Públicos porque eles, presumidamente, cumprem uma função social, encontrando-se afetados a um determinado interesse público, de forma a serem propiciados benefícios que deverão ser usufruídos pela coletividade.

Com efeito, cumpre observar que tais previsões constitucionais de proibição de aquisição por usucapião especial pro morare ou pro labore dos Bens Públicos, não pode servir como pretexto para que se legitime a inércia do Estado com relação aos bens que compõem o seu patrimônio e obstar a incidência da usucapião nos casos que envolvem particulares quando estes observam o princípio constitucional da função social da propriedade e preencham os demais requisitos legais incidentes sobre os Bens Formalmente Públicos, porque isso implicaria em restrição a que eles tenham o direito constitucional de moradia (no caso de imóvel urbano) e o de trabalho (em se

\footnotetext{
${ }^{55}$ SILVA, José Afonso da, op. cit., p. 315.

${ }^{56}$ GAMA, Guilherme Calmon Nogueira; OLIVEIRA, Andrea Leite Ribeiro de, op. cit., p. 66. Posteriormente, referidos autores destacam a importância exercida pela posse como elemento central da usucapião e indispensável para conferir função social à propriedade quando, a partir da ponderação de valores e interesses, dispõe ser aquela (posse) o instituto jurídico que "serve à vida, proporcionando alimentos e moradia - como no caso do imóvel -, garantindo vida digna".
} 
tratando de imóvel rural), assegurados.

Por fim, cumpre destacar que a Súmula 340 do Supremo Tribunal Federal - cujo teor corrobora, em sede de instituto unificador de jurisprudência, a imprescritibilidade dos Bens Públicos - foi editada antes da promulgação da Constituição Federal de 1988 e faz referência ao Código Civil de 1916. Esta constatação demonstra a discrepância entre o contexto social e jurídico em que o enunciado sumular foi elaborado e o atual cenário, bem como entre os valores normativos contidos na atual Ordem Constitucional, avocando a necessidade de se efetuar a reinterpretação da questão à luz da atual Constituição. Com isso, é imperiosa a reavaliação da questão concernente à viabilidade da incidência da usucapião como forma de aquisição da propriedade de Bens Formalmente Públicos, por particulares como forma de concretização do Princípio Constitucional da Função Social da Propriedade, de modo a estimular o Poder Público a evitar de se omitir e atribuir constantemente a almejada finalidade pública aos bens que fazem parte do seu patrimônio.

\section{CONSIDERAÇÕES FINAIS}

Uma visão panorâmica sobre a questão concernente à necessidade de observância do Princípio da Função Social da Propriedade, inclusive pelo Poder Público, sob pena de admitir-se a aquisição dos Bens Formalmente Públicos por usucapião, em caso de omissão, foi a tônica impressa durante o desenrolar deste estudo, até porque referido princípio foi incluído no rol dos Direitos e Garantias Fundamentais pela Constituição Federal Brasileira, promulgada no ano 1988 (art. 5, XXIII, CF), ocorrendo a sua manutenção na base normativa constitucional referente à Ordem Econômica, (art. 170, inciso III, CF), relativizando-se e flexibilizando-se conceitos e paradigmas atinentes ao Direito de Propriedade, que deixou de ser absoluto a partir daquele memorável instante.

Ademais, o novo substrato conferido ao conceito do Direito de Propriedade e a consequente exigência constitucional de atendimento à sua função social implica na necessidade de se efetuar uma reinterpretação das normas contidas no Ordenamento Jurídico Brasileiro, sobretudo no que tange aos dispositivos constitucionais que vedam expressamente a usucapião especial pro moraree pro labore de Bens FormalmentePúblicos (arts. 183, $\$ 3^{\circ}$ e 191, parágrafo único, ambos da Constituição Federal), interpretando-os, por conseguinte, segundo a dicção principiológica constitucional de forma integral - notadamente quanto ao Princípio da Função Social da Propriedade.

Depreende-se, assim, que todos os bens devem cumprir uma função social - até mesmo em razão da exigência constitucional -, independentemente de quem seja o seu titular (particular ou pessoa jurídica de direito público interno), como pressuposto indispensável para garantir que o Direito de Propriedade seja

\footnotetext{
${ }^{57}$ MEDAUAR, Odete, op. cit., p. 253.
} vol.09, nº. 04, Rio de Janeiro, 2016.pp. 2507-2525 
constitucionalmente tutelado.

Para analisar a possibilidade de incidência da usucapião sobre Bens Públicos em determinadas situações excepcionais, necessário se fez a classificação e consequente distinção entre Bens Materialmente Públicos e Bens Formalmente Públicos. Ademais, também se tornou relevante a classificação dos Bens Públicos segundo a sua destinação: Bens Públicos de uso comum; de uso especial; e dominicais.

Nesse sentido, embora ainda seja majoritário o entendimento de que a vedação constitucional da possibilidade de aquisição por usucapião de Bens Públicos seja absoluta e não comporta exceção alguma, restou demonstrado que já há doutrinadores e entendimentos jurisprudenciais recentes que convergem no sentido de admitir a viabilização da usucapião de Bens Formalmente Públicos. Tal tendência vem adquirindo destaque, frente à interpretação finalística e sistemática e não mais, meramente exegética, das normas constitucionais.

Com efeito, os Bens Públicos de uso comum e os de uso especial, por estarem afetados a um determinado interesse público - resguardadas as suas peculiaridades -, de certa forma, já cumpririam a sua função social.

De outro lado, os Bens Públicos Dominicais por estarem desafetados, isto é, por se encontrarem desvinculados de uma finalidade de interesse público, podem ser considerados como Bens Formalmente Públicos. Isto porque, embora tais bens sejam de titularidade do Estado, ao preencherem apenas uma posição formal desprovida de afetação, não estariam cumprindo sua função social ante a ausência de vinculação destes bens a um determinado interesse público.

Assim, ante a ausência de atribuição de função social aos Bens Formalmente Públicos pelo Estado, o que se infere é que se torna plenamente possível a aquisição da propriedade pelo particular, pela usucapião especial pro morare ou pro labore, o que serve até mesmo como instrumento para garantir a observância do Princípio Constitucional da Função Social da Propriedade e, consequentemente, como forma de efetivação dos Direitos Fundamentais Coletivos, especialmente, o de moradia.

Desta forma, a vedação constitucional à incidência da usucapião especial pro moraree pro labore contida expressamente no texto constitucional (arts. 183, $\$ 3^{\circ}$ e 191, parágrafo único, ambos da Constituição Federal) abarca somente os Bens Materialmente Públicos, ainda que tais dispositivos não contemplem nenhuma ressalva, uma vez que se faz necessária uma interpretação finalística e sistemática do Ordenamento Jurídico Constitucional em conjunto com a força normativa dos seus princípios - notadamente com o Princípio da Função Social da Propriedade.

Por fim, embora haja entendimento do Supremo Tribunal Federal, consolidado no enunciado da Súmula 340, no sentido de que os Bens Dominicais, assim como os demais Bens Públicos, não ensejam a incidência da usucapião, verifica-se que tal posicionamento deve ser revisto sob a ótica dos valores principiológicos e normativos contidos na Constituição Federal de 1988, já que tal enunciado foi proferido pela vol.09, no. 04, Rio de Janeiro, 2016. pp. 2507-2525 2522 
Suprema Corte em período anterior à sua promulgação e está em dissonância com a principiologia constante da atual Ordem Jurídica Constitucional, que privilegia a necessidade de observação estrita ao Princípio da Função Social da Propriedade e de outros Direitos Fundamentais a ela imanentes.

\title{
INCIDENCE OF USUCTION IN THE FORMAL PUBLIC PROPERTY: INSTRUMENT OF EFFECTIVENESS TO THE CONSTITUTIONAL PRINCIPLE OF THE SOCIAL FUNCTION OF PROPERTY AND COLLECTIVE FUNDAMENTAL RIGHTS
}

\begin{abstract}
The possibility of incidence of usucapio on public goods in the Democratic State of Brazilian Law should be studied because the absolute inadmissibility in reason of strict interpretation of articles 183 , $\$ 3^{\circ}$ e 191 , single paragraph, both the Federal Constitution of 1988, accompanied by the majority doctrinal and jurisprudential position - this same understanding is overviews by the Supreme Court (Summary 340) - is confronted by constitutional values and normative principles (especially as the Principle of Social Function of Property). Then some important law researchers that defend the positioning - with support in recent jurisprudence - that just some public goods would be protected by constitutional prohibition of usucapio: Materially Public Goods. Therefore, the Formally Public Goods (notably Public Goods "Dominiais" - that don't have public function) could be object of usucapio - in exception situations - because this institute is an important instrument to materialize the Principal of Social Function of Property and effective fundamental rights, for example, the habitation social right.
\end{abstract}

Keywords: Formally Public Goods; Social Function of Property; Acquisition by Usucapio; Prescription.

\section{REFERENCIAS}

ALBUQUERQUE, Ana Rita Vieira. Da função social da posse. Rio de Janeiro: Lumen Juris, 2002.

ALEXANDRINO, Marcelo; PAULO, Vicente. Direito administrativo descomplicado. São Paulo: Método, 2014.

AMARAL, Francisco. Direito civil: introdução. Rio de Janeiro: Renovar, 2002.

ARAÚJO, Fabio Caldas de. O usucapião no âmbito material e processual. Rio de Janeiro: Forense, 2002.

BASTOS, Celso Ribeiro. Curso de direito administrativo. São Paulo: Celso Bastos, 2002.

BRAZ, Petrônio. Manual de direito administrativo. Leme: Editora de Direito, 2001.

CARVALHO FILHO, José dos Santos. Manual de direito administrativo. 27. ed. Rio de Janeiro: Lumen Juris, 2014.

CASTRO, Mariângela Conceição Vicente Bergamini de. O princípio da função social da propriedade: empresa. 
(Dissertação) Universidade de Marília, Marilia, 2008.

COMPARATO, Fabio Konder. A reforma da empresa. São Paulo: Saraiva, 1995.

CORDEIRO, Carlos José. Usucapião constitucional urbano: aspectos de direito material. São Paulo: Max Limonad, 2001.

CRETELLA JÚNIOR, José. Manual de direito administrativo. Rio de Janeiro: Forense, 2005.

DANTAS, Francisco Wildo Lacerda. A reforma agrária e a usucapião pro labore. In: Revista de Informação

Legislativa. Brasília: Senado Federal, Subsecretaria de Edições Técnicas, ano 33, n. 131, jul./set., 1996.

DI PIETRO, Maria Sylvia Zanella. Direito administrativo. São Paulo: Atlas, 2012.

DOWER, Nelson Godoy Bassil. Curso moderno de direito civil São Paulo: Nelpa, 2004.

DUGUIT, Leon. Derecho subjetivo y la función social. In: Las transformaciones del derecho (público y privado). Trad. Carlos Posada. Buenos Aires: Heliasta, 1975.

ESPÍNOLA, Eduardo. Posse, propriedade, compropriedade ou condomínio, direitos autorais. Campinas: Bookseller, 2002.

FARIAS, Cristiano Chaves de; ROSENVALD, Nelson. Direitos reais. Rio de Janeiro: Lumen Juris, 2006.

FORTINI, Cristiana. A função social dos bens públicos e o mito da imprescritibilidade. Revista Brasileira de Direito Municipal, Belo Horizonte, ano 5, n. 12, abril/junho, 2004.

FRANCO, Vera Helena de Mello. A função social da empresa. Revista do Advogado, São Paulo, ano 28, v. 96, mar. 2008

GAMA, Guilherme C. Nogueira; OLIVEIRA, Andrea Leite Ribeiro de. Função social da propriedade e da posse. In: GAMA, Guilherme Calmon Nogueira da. (Coord.). Função social no direito civil. São Paulo: Atlas, 2008.

GASPARINI, Diogenes. Direito administrativo. São Paulo: Saraiva, 2011.

GONDINHO, André Osorio. Função social da propriedade. In: TEPEDINO, Gustavo. Problemas de direito civil-constitucional. Rio de Janeiro: Renovar, 2000.

LÔBO, Paulo. Direito civil: parte geral. São Paulo: Saraiva, 2012.

MARÇAL, Thaís Boia; OLIVEIRA, Rafael Carvalho Rezende. A função social e a usucapião de bens públicos: uma releitura a partir da constitucionalização do ordenamento jurídico. Boletim de Direito Administrativo BDA, São Paulo: NDJ, dez/2013.

MEDAUAR, Odete. Direito administrativo moderno. São Paulo: Revista dos Tribunais, 2010.

MEIRELES, Hely Lopes. Direito administrativo brasileiro. São Paulo: Malheiros, 2010.

MELLO, Celso Antônio Bandeira de. Curso de direito administrativo. 27. ed. São Paulo: Malheiros, 2010. p. 
MORAES, José Diniz de. A função social da propriedade e a Constituição Federal de 1988. São Paulo: Malheiros, 1999 .

NADER, Paulo. Curso de direito civil: parte geral. Rio de Janeiro: Forense, 2003.

OLIVEIRA, Arlindo Uilton de. Usucapião urbano e rural. Presidente Prudente: Data juris, 1994.

PESTANA, Marcio. Direito administrativo brasileiro. Rio de Janeiro: Elsevier, 2008.

RÁO, Vicente. O Direito e a vida dos direitos. São Paulo: Revista dos Tribunais, 2013.

RIBEIRO, Benedito Silvério. Tratado de usucapião. São Paulo: Saraiva, 2012.v. 1.

SALLES, José Carlos de Moraes. Usucapião de bens imóveis e móveis. 2. ed. Rio de Janeiro: Revista dos Tribunais, 1992.

SILVA, José Afonso da. Curso de direito constitucional positivo. 24. ed. São Paulo: Malheiros, 2005.

ZACARIAS, André Eduardo de Carvalho. Anotações sobre a usucapião: de acordo com a Lei n. 10.406/2002. Leme: Edijur, 2006.

Trabalho enviado em 07 de março de 2016.

Aceito em 14 de julho de 2016. 